\title{
UPAYA MENINGKATKAN PERILAKU MINIM SAMPAH MELALUI METODE HULU BAGI SANTRIWATI Antinah Latif ${ }^{*}$, \\ ${ }^{1}$ Teknik Grafika, POLITEKNIK NEGERI MEDIA KREATIF, Indonesia antinahlatif@polimedia.ac.id
}

\begin{abstract}
ABSTRAK
\section{Abstrak:}

Pesantren sebagai salah satu tempat yang memiliki potensi sampah yang tinggi jika tidak dikelola dengan baik. Perlunya pengelolaan sampah dari hulu hingga volume sampah dapat berkurang. Berdasarkan hasil observasi bahwa sampah belum dikelola dengan baik yaitu belum adanya pengolahan sampah. Tujuan dari pengabdian ini adalah untuk meningkatkan kesadaran perilaku minim sampah kepada santri dengan metode pengelolaan sampah dan pembuatan eco-enzym. Metode yang digunakan adalah penyuluhan dan praktik pembuatan eco-enzym. Sasarannya adalah seluruh santri markaz Alquran Akhwat Indonesia sebanyak 21 santri baru. Metode pelaksanaan yang dilakukan dalam kegiatan ini terdiri dari pra kegiatan, kegiatan dan evaluasi. Evaluasi yang dilakukan adalah dengan memberikan ujian pre dan post test untuk mengetahui peningkatan pengetahuan dan keterampilan pembuatan eco-enzym. Hasil yang telah dicapai adalah terjadinya peningkatan pengetahuan perilaku minim sampah sebesar 5,2\%. Adapun pembuatan eco-enzyme sudah sesuai dengan prosedur.
\end{abstract}

Kata Kunci: Perilaku minim sampah; Metode hulu; Pengolahan sampah; Santri dan Pesantren.

\begin{abstract}
:
Islamic Boarding School as a place that has a high potential for waste if not managed properly. The need for waste management from upstream to the volume of waste can be reduced. Based on the observation that the waste has not been managed properly, namely the absence of waste processing. The purpose of this service is to increase awareness of minimal waste behavior to students with waste management methods and the manufacture of eco-enzymes. The method used is counseling and the practice of making eco-enzymes. The target is all students of the Indonesian Akhwat Al-Quran Markaz as many as 21 new students. The implementation method carried out in this activity consists of preactivity, activity and evaluation. The evaluation is done by giving pre and post tests to determine the increase in knowledge and eco-enzyme skill. The result that has been achieved is an increase in knowledge of minimal waste behavior in 5,2\%. The manufacture of eco-enzyme is in accordance with the procedure.
\end{abstract}

Keywords: minimal waste behavior; upstream method; Waste processing; Students and Islamic Boarding Schools.

\section{A. LATAR BELAKANG}

Saat ini konsep pengelolaan sampah mengalami pergeseran. Paradigma lama saat ini sudah seharusnya ditinggalkan dan beralih kepada paradigma baru. Berdasarkan amanah UU RI No 18 Tahun 2008 terkait pengelolaan sampah, paradigma baru ditekankan adanya upaya yang terus menerus dengan pengurangan volume sampah sejak hulu/awal dari rumah masing-masing atau sumbernya. Secara umum permasalahan yang dihadapi di Indonesia adalah perilaku hidup minim sampah yang belum terbangun. Masyarakat cenderung membuang sampah tidak sesuai pada tempatnya, tidak peduli terhadap pemilahan jenis sampah dan tidak mau dan mampu untuk mengelola sampahnya dari sumber sehingga meninggalkan tanggung jawabnya kepada para pengangkut sampah atau kepada petugas kebersihan sehingga volume sampah menjadi masalah bersama (O.R. \& N., 2020). Berbagai perilaku manusia tersebut akhirnya menjadikan lingkungan sebagai tempat yang penuh dengan ancaman bahkan sering menyebabkan konflik social yang berdampak pada kesehatan, keselamatan dan estetika (Mahyudin, 2017). 
Pesantren di Indonesia mencapai 28 ribu bahkan jumlah santri di Indonesia mencapai tiga (3) juta. Potensi luar biasa yang dimiliki oleh Indonesia untuk menghasilkan generasi yang tidak hanya menonjol dibidang keagamaan tetapi juga menonjol pada sisi keilmuan dan teknologi atau dikenal dengan istilah IMTAK DAN IMTEK. Pesantren juga menghasilkan potensi sampah yang luar biasa jika tidak dikelola dengan baik (Auvaria, 2016). Masih dijumpainya perilaku membuang sampah bukan pada tempatnya dan masih ditemukan adanya pembakaran sampah (Pudjiastuti, 2020). Kesadaran akan pengolahan sampah di pesantren harus terus ditingkatkan (Iffandani et al., 2013). Namun, beberapa pesantren juga sudah mulai bergerak untuk peduli terhadap lingkungan. Salah satu kegiatan yang dilaksanakan adalah dengan pengelolaan sampah dari hulu ke hilir, seperti pesantren modern Al Barokah. Pesantren tersebut sudah mampu memilah dan mengolah sampah baik jenis organik maupun anorganik dan pembuatan biopori (Huda \& Rajagukguk, 2020). Kegiatan menjaga lingkungan merupakan kewajiban Bersama dalam rangka menjaga ciptaan Allah swt termasuk oleh para santri di pesantren (Rofifah, 2020). Saat ini telah dikembangkan eco-pesantren yang dapat diadopsi berbagai pesantren untuk mewujudkan pesantren yang sadar lingkungan. Namun evaluasi yang didapatkan bahwa pelaksanaan eco-pesantren belum sepenuhnya dipahami pentingnya pelaksanaan system tersebut (Fahham, 2019).

Pesantren Markaz Quran Akhwat Indonesia merupakan salah satu pesantren tahfidz di daerah perkotaan. Berdasarkan hasil observasi dan wawancara, selama ini pembuangan sampah mengikuti pola pengangkutan sampah di DKI Jakarta khususnya adalah di Jakarta Timur, Pasar Rebo, Kalisari. Sampah yang dihasilkan santri beragam mulai dari sampah organik berupa sisa makanan, sisa dapur dan tanam-tanaman. Adapun sampah yang sulit terurai adalah sampah kemasan dan plastik atau kantong kresek. Selama ini, santri belum memerhatikan pola pencegahan, pemilahan dan pengolahan sampah dengan baik. Santri cenderung mencampur semua sampah baik sampah jenis organik dan non organik. Hal tersebut berdampak pada kenyamanan penghuni asrama atau pondok yang menimbulkan bau tidak sedap apabila sampah tidak segera diangkut oleh petugas kebersihan setempat.

Berdasarkan hasil penelitian pada tahun 2019 bahwa semua santri tahu tentang perintah menjaga lingkungan yang terdapat dalam Alquran dan hadis, mengetahui dampak plastik terhadap ekosistem sebanyak $68,5 \%$, lama teruainya sampah botol plastik $50 \%$ menjawab benar, serta pengetahuan tentang cara pencegahan sampah plastik hampir menjawa benar di atas 50\%. Namun belum mengetahui cara pencegahan sampah dengan metode ecoenzyme dan ecobricks. Adapun terkait sikap, dapat disimpulkan bahwa sebagian besar menunjukkan sikap baik terhadap perhatian pemilahan sampah, perasaan bersalah ketika membuang sampah sembarangan, penerimaan terhadap kendaraan umum, memilih kemasan lebih besar yang didapatkan dengan hasil lebih dari 50\% menjawab setuju/sangat setuju. Sedangkan perilaku/tindakan minim sampah santri di pesantren MQAI menunjukkan perilaku yang cukup baik atau kurang. Hal tersebut dapat terlihat dengan capaian perilaku berikut: tindakan membuang sampah pada tempatnya, membawa wadah makan dan minum secara mandiri, selalu menghabiskan sisa makanan, mengurangi sampah kantong kresek dengan prosentasi di atas 50\% santri telah melakukan tindakan minim sampah di atas. Adapun perilaku minim sampah yang masih perlu ditingkatkan adalah belum membuat kompos sebagai pengurangan sampah organik, masih sering menggunakan tissue, belum memisahkan sampah sesuai jenisnya, tidak menerapkan ecobricks, belum mampu menolak penggunaan kantong kresek, belum memanfaatkan minyak jelantah, masih menggunakan kemasan kecil, tidak memanfaatkan hasil ecoenzyme dalam membesihkan rumah, dan masih menggunakan sedotan. Prosentasi dari tindakan di atas mencapai di atas 50\%. Selain itu, santri belum mampu mengelola sisa konsumsi organic dengan menggunakan metode kompos, dan ecoenzyme dan sisa konsumsi nonorganic dengan metode ecobricks. 
Berdasarkan hasil penelitian yang dilakukan sebelum pengabdian masyarakat tersebut, maka perlunya dilakukan upaya meningkatkan perilaku minim sampah bagi santri melalui metode hulu yaitu dengan pengolahan sampah (3 $\mathrm{AH}$ atau pemilahan sampah organic dan anorganik) dan pembuatan eco-enzyme. Dengan metode hulu tersebut diharapkan dapat mengurangi sampah sejak hulu sehingga volume sampah dapat berkurang secara signifikan. Tujuan dari upaya meningkatkan perilaku minim sampah bagi santri adalah adanya peningkatan perilaku minim sampah mulai dari pengetahuan, sikap dan perilaku minim sampah santri. Perilaku yang diharapkan adalah terwujudnya pengolahan sampah seperti pencegahan sampah, pemilahan sampah mulai dari anorganik dan organic, dan pengolahan sampah dengan pembuatan compost dan eco-enzyme.

\section{B. METODE PELAKSANAAN}

\section{Metode PelaksanaAn}

Metode yang digunakan dalam pelatihan minim sampah di pesantren adalah dengan metode penyuluhan dan praktik pembuatan eco-enzyme dengan tema Peningkatan Perilaku Minim Sampah dengan Metode Hulu yaitu pengolahan sampah dan pembuatan eco-enzym. Metode penyuluhan tentang pengolahan sampah dengan metode 3R pernah dilakukan di pesantren sabilunnajat di Ciamis dan menghasilkan adanya peningkatan pengetahun (Fajrini et al., 2020). Begitu juga metode penyuluhan tentang pengolahan sampah $4 \mathrm{R}$ di daerah Gresik yang terbukti bisa meningkatkan pengetahuan dan keterampilan dalam pengolahan sampah khususnya dengan bank sampah (Kusminah, 2018).

\section{Deskripsi Mitra}

Markaz Alquran Akhwat Indonesia (MQAI) merupakan bagian dari Markaz Quran Indonesia yang beralamat di Kalisari, Jakarta Timur. Markaz Alquran Akhwat Indonesia merupakan salah satu pesantren tahfidzul quran yang bervisikan menjadikan santri yang Hafidzah, Da'iyah dan Mujahidah. Kelak dari santri tersebut mampu melahirkan generasi ummahatul mukminin yang mampu bermanfaat untuk ummat islam di lingkungannya. Santri MQ Akhwat Indonesia memiliki perilaku yang cukup baik namun perlu ditingkatkan untuk peduli terhadap masalah lingkungan khususnya masalah sampah di lingkungan pesantren. MQAI saat ini memiliki 3 asrama yang tersebar di daerah Kalisari dengan jumlah santri lebih dari 30 orang. Adapun yang terlibat dalam pelatihan hidup minim sampah ini adalah 24 peserta yang berstatus sebagai santri baru. Selain itu juga diikuti oleh para pengelola sehingga bisa tercapai keseimbangan pengetahuan dan kesadaran antara pengelola sebagai pihak pemberi fasilitas dan santri sebagai pihak yang akan menjalankan dan memanfaatkan program tersebut. Pemberian penyuluhan kepada masyarakat membutuhkan dukungan stakeholder sehingga program dapat berjalan lebih efektif (Anggreana et al., 2021).

\section{Langkah-langkah Pelaksanaan}

Metode yang digunakan dalam pelatihan minim sampah di pesantren terdiri dari pra kegiatan, kegiatan dan pelaksanaan action plan serta evaluasi.

a. Pra kegiatan diisi dengan observasi dan wawancara serta pencarian data sekunder.

b. Tahap kegiatan adalah pemberian materi menggunakan metode penyuluhan yang dibantu dengan power point dan video

c. Langkah selanjutnya adalah Simulasi atau praktik pembuatan ecoenzyme yang dibagi menjadi 2 kelompok besar. 
d. Action plan. Kegiatan ini sebagai tindak lanjut kegiatan program sehingga upaya perilaku minim sampah dapat berjalan dengan baik.

e. Kegiatan evaluasi terbagi menjadi dua yaitu selama pelatihan dan setelah pelatihan. Evaluasi selama pelatihan adalah dengan memberikan kuesioner pre-test dan post-test untuk menilai perilaku minim sampah oleh santri. adapun kegiatan evaluasi setelah pelatihan penyuluhan adalah dengan melakukan pemantauan terhadap action plan yang sudah berjalan.

\section{HASIL DAN PEMBAHASAN}

1. Pelatihan ini dilaksanakan pada tanggal 17 Oktober 2021 bertempat di Aula Markaz Quran Akhwat Indonesia. Berlokasi di daerah perkotaan yaitu Kalisari, Pasar Rebo, Jakarta Timur. Peserta yang mengikuti pelatihan ini sebanyak 24 santri. Usia santri yang mengikuti pelatihan yang paling rendah adalah 15 tahun dan usia yang paling tinggi adalah usia 25 tahun. Rata-rata pendidikan adalah tamatan SD, SMP dan tidak teridentifikasi (9 santri), dan SMA (13 santri), adapun yang tamatan S1 hanya 2 orang santri. Adapun system pengelolaan sampah yang selama ini dilaksanakan adalah mengikuti aturan daerah kota setempat. Aturan tersebut adalah setiap rumah/instansi termasuk pesantren menyimpan sampah baik yang dipilah atau tidak kemudian akan diangkut langsung oleh petugas kebersihan, setelah itu akan diangkut menuju TPA akhir. Sistem pengelolaan sampah di Markaz Alquran Akhwat Indonesia diterapkan secara mandiri tanpa adanya pelibatan dari pihak pengelola pesantren. Sistem kemandirian tersebut menjadi peluang sekaligus ancaman bagi santri apabila tidak mampu dikelola dengan baik. Melalui adanya pelatihan pembuatan ecoenzyme dan pemahaman tentang pencegahan, pemilahan dan pengolahan sampah ini diharapkan mampu mengurangi volume sampah di lingkungan pesantren.

a. Pra kegiatan diisi dengan observasi dan wawancara dengan pengelola pesantren terkait dengan pengolahan sampah yang selama ini dilakukan oleh santri di pesantren. Selain itu dalam tahap pra kegiatan mencari data sekunder terkait pengetahuan santri, sikap dan perilaku santri pada beberapa tahun sebelumnya yaitu tahun 2019 berdasarkan hasil laporan pengabdian masyarakat sebelumnya.

b. Tahap kegiatan adalah pemberian materi menggunakan metode penyuluhan. Kegiatan ini diawali dengan penyambutan oleh pengelola pesantren dilanjutkan dengan pembacaan Alquran oleh perwakilan santri, dan pengisian pre-test untuk peserta. Setelah pengisian pre-test langkah selanjutnya adalah pemberian materi (Gambar 1). Materi disampaikan selama kurang lebih 1 jam dengan alat bantu power point dan video tentang "tobat sampah plastik". Selama pengisian materi, agar tidak bosan, pemateri meminta peserta untuk diskusi kelompok terkait mengidentifikasi jenisjenis sampah yang dihasilkan oleh santri kemudian dipresentasikan (Gambar 2). Setelah itu diadakan tanya jawab. 


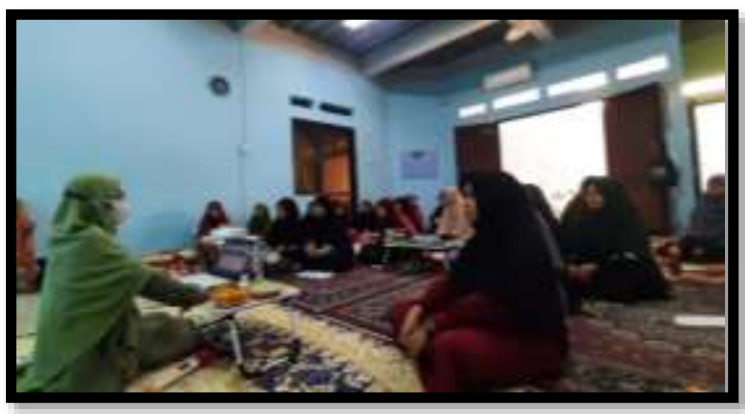

Gambar 1. Pemberian Materi

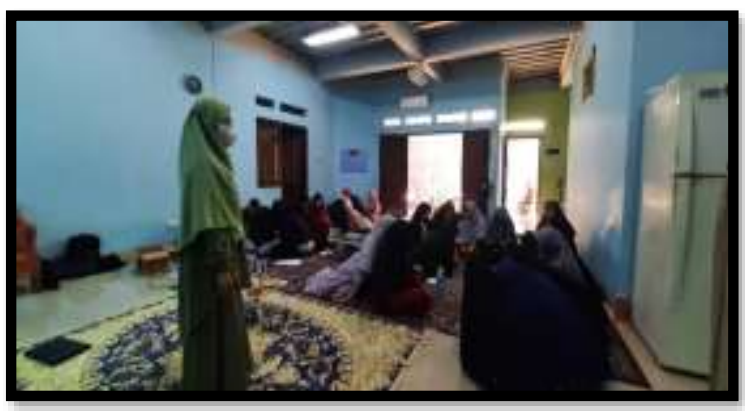

Gambar 2. Diskusi Kelompok

c. Langkah selanjutnya adalah Simulasi atau praktik pembuatan ecoenzyme yang dibagi menjadi 2 kelompok besar. Kegiatan praktik pembuatan ecoenzyme ini dengan memanfaatkan kulit jeruk, gula merah, air dan botol minum kemasan yang telah terkumpul hasil pemilihan sampah. Dalam kegiatan ini dijelaskan langkah-langkah pembuatannya dan santri langsung mendemonstrasikan. Selain itu juga dijelaskan berbagai macam manfaatnya dan pengertiannya. Eco-enzym ini dapat digunakan untuk berbagai keperluan rumah tangga seperti mengepel, mengelap bahkan dapat dijadikan sebagai handsanitizer (Alkadri \& Asmara, 2020; (Junaidi et al., 2021).

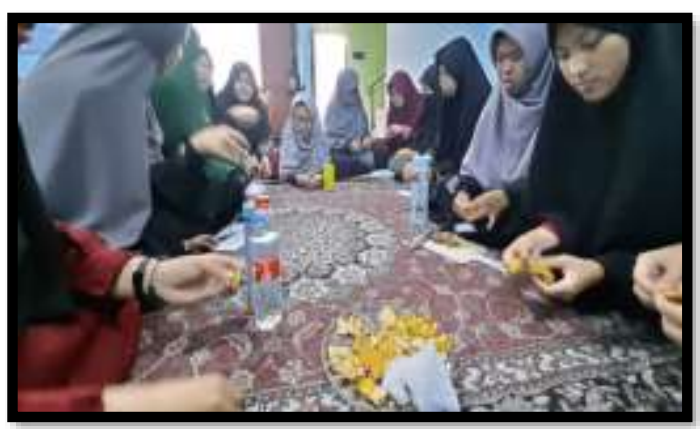

Gambar 3. Pembuatan Eco-enzym Kelompok 1 


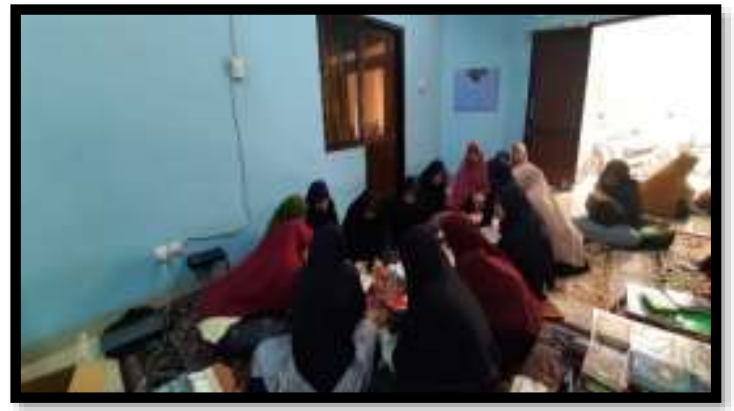

\section{Gambar 4. Pembuatan Eco-enzym Kelompok 2}

d. Action plan. Kegiatan ini sebagai tindak lanjut kegiatan program sehingga upaya perilaku minim sampah dapat berjalan dengan baik. Pada langkah ini adalah dipilihnya dua project leader untuk dua asrama yang ada di pesantren.

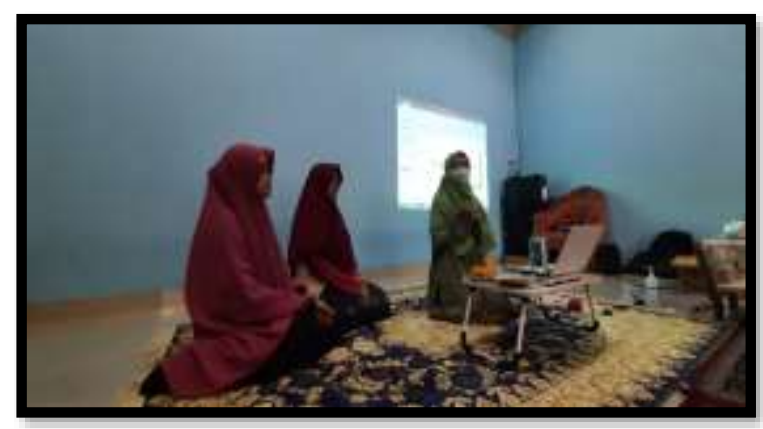

Gambar 5. Pembimbingan Action Plan

2. Kegiatan evaluasi terbagi menjadi dua yaitu selama pelatihan dan setelah pelatihan. Evaluasi selama pelatihan adalah dengan memberikan kuesioner pretest dan post-test untuk menilai perilaku minim sampah oleh santri. Adapun kegiatan evaluasi setelah pelatihan penyuluhan adalah dengan melakukan pemantauan terhadap action plan yang sudah berjalan. Berikut adalah hasil evaluasi sebelum dan setelah mengikuti penyuluhan tentang perilaku minim sampah:

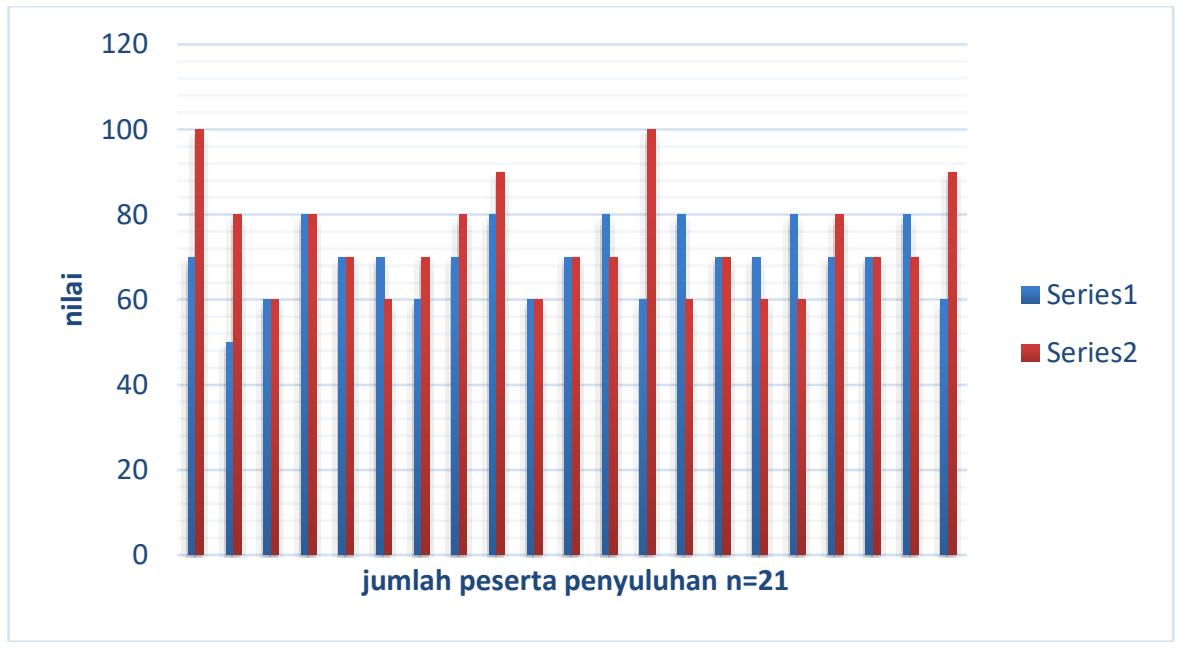

Gambar 6. Perbandingan Nilai Sebelum dan Setelah Penyuluhan 
Pre-test dilakukan untuk mengetahui pengetahuan awal para santri terkait perilaku minim sampah mulai dari jenis sampah, fakta sampah, pengolahan sampah dari cegah, pilah dan olah serta pembuatan ecoenzym. Sedangkan setelah proses penyuluhan diadakan post-test untuk mengetahui seberapa efektif metode ini dilaksanakan. Series 1 menandakan pre-test sedangkan series 2 adalah adalah post-test. Berdasarkan hasil statistika tidak ada perbedaan yang signifikan antara sebelum dan setelah penyuluhan. Namun mengalami peningkatan sebesar 5,2\% berdasarkan perhitungan rumus N-Gain. Adapun pengetahuan yang harus menjadi perhatian adalah tentang fakta sampah anorganik di Indonesia dan ecobrick. Pengetahuan umum terkait perilaku minim sampah yang sudah diketahui santri adalah pengetahuan terkait contoh pengolahan sampah (re-use) dan jenis sampah (anorganik dan organic).

3. Kendala dan Solusi

Berikut adalah kendala dan solusi yang dihadapi selama proses kegiatan penyuluhan dan praktik pembuatan eco-enzyme.

\begin{tabular}{|l|l|}
\hline Kendala & Solusi \\
\hline $\begin{array}{l}\text { Belum tersedianya bahan dan alat } \\
\text { untuk praktik pengolahan sampah } \\
\text { terutama untuk kompos }\end{array}$ & $\begin{array}{l}\text { Alternative praktik pengolahan } \\
\text { sampah dengan eco-enzyme dan } \\
\text { adanya penambahan strategi } \\
\text { penyuluhan yaitu dengan adanya } \\
\text { games identifikasi jenis sampah }\end{array}$ \\
\hline Waktu penyuluhan terbatas & $\begin{array}{l}\text { Tindak lanjut kegiatan } \\
\text { pascapenyuluhan dan dibentuknya } \\
\text { leader project }\end{array}$ \\
\hline
\end{tabular}

\section{SIMPULAN DAN SARAN}

Kegiatan penyuluhan perilaku minim sampah di pesantren dapat meningkatkan kesadaran dengan adanya perubahan pengetahuan setelah dilakukan penyuluhan meskipun perubahannya tidak begitu signifikan. Oleh karena itu perlu dilakukan pemantauan dan tindak lanjut dari program tersebut dan perlunya dukungan dari pengelola pesantren untuk menyediakan fasilitas pengolahan sampah.

\section{UCAPAN TERIMA KASIH}

Tim penulis mengucapakan terima kasih kepada pihak pengelola Markaz Alquran Akhwat Indonesia yang telah memberikan kesempatan sehingga acara ini dapat berjalan dengan lancar.

\section{DAFTAR RUJUKAN}

Alkadri, S. P. A., \& Asmara, K. D. (2020). Pelatihan Pembuatan Eco-Enzyme Sebagai Hand sanitizer dan Desinfektan Pada Masyarakat Dusun Margo Sari Desa Rasau Jaya Tiga Dalam Upaya Mewujudkan Desa Mandiri Tangguh Covid-19 Berbasis Eco-Community. Jurnal Buletin Al-Ribaath, 17(2), 98. https://doi.org/10.29406/br.v17i2.2387

Anggreana, V., Alwiah, S. S., Purnamawati, N., Mildawati, R., \& Harmiyati, H. (2021). Abdimas galuh. 3, 173-182.

Auvaria, S. W. (2016). Perencanaan Pengelolaan Sampah di Pondok Pesantren Langitan Kecamatan Widang Tuban. Al-Ard: Jurnal Teknik Lingkungan, 2(1), 1-7. https://doi.org/10.29080/alard.v2i1.126 
Fahham, A. M. (2019). Sanitasi dan Dampaknya bagi Kesehatan: Studi dari Pesantren. Jurnal Aspirasi, 10(1), 33-47. https://doi.org/10.22212/aspirasi.v10i1.1230

Fajrini, F., Elyasa, L. B., Alfiana, Q., Masyarakat, J. K., \& Jakarta, U. M. (2020). Edukasi Dan Pendampingan Pengolahan Sampah Berbasis 3R ( Reduce, Reuse, Recycle ) Pada Santri Di Pesantren Sabilunnajat, Ciamis 3R (Reduce, Reuse, Recycle) Waste Processing Education and Facilities in Santri in Sabilunnajat Pesantren ,. 1, 16-22.

Huda, M. K., \& Rajagukguk, S. (2020). Penguatan Karakter Peduli Lingkungan di Pesantren Modern Al Barakah Melalui Pengelolaan Sampah dan Pemanfaatan Biopori. BEST Journal, 3(2), 198-204.

Iffandani, D., Muttaqien, S., G, O. R., Pengajar, S., Sipil, J. T., \& Teknik, F. (2013). Penerapan 3R. DEDIKASI, 10, 45-54.

Junaidi, M. R., Zaini, M., Ramadhan, Hasan, M., Ranti, B. Y. Z. B., Firmansyah, M. W., Umayasari, S., Sulistyo, A., Aprilia, R. D., \& Hardiansyah, F. (2021). Pembuatan Eco Enzyme Sebagai Solusi Pengolahan Limbah Rumah Tangga. Jurnal Pembelajaran Pemberdayaan Masyarakat, 2(2), 118-123.

Kusminah, I. L. (2018). Penyuluhan 4R (Reduse, Reuse, Recycle, Replace) dan Kegiatan Bank Sampah Sebagai Langkah Menciptakan Lingkungan yang Bersih dan Ekonomis di Desa Mojowuku Kab. Gresik. JPM17: Jurnal Pengabdian Masyarakat, 3(01), 22-28. http://jurnal.untag-sby.ac.id/index.php/jpm17/article/view/1165

Mahyudin, R. P. (2017). Kajian Permasalahan Pengelolaan Sampah Dan Dampak. Teknik Lingkungan, 3, 3(1), 66-74.

O.R., T., \& N., K. (2020). Penyuluhan Pengelolan Sampah Dengan Konsep 3R Dalam Mengurangi Limbah Rumah Tangga. Cakrawala, 4(2), 153-168. https://ejournal.iainukebumen.ac.id/index.php/cka/article/view/250

Pudjiastuti, S. R. (2020). Improving Student (Santri) Care for the Living Environment in Nurul Huda Islamic Boarding School, Depok. Jhss (Journal of Humanities and Social Studies), 4(1), 01-04. https://doi.org/10.33751/jhss.v4i1.1912

Rofifah, D. (2020). No Title No Title No Title. BRILIANT: Jurnal Riset Dan Konseptual, 4, 12 26. 